\title{
MANFAAT ASUHAN COUNTER-PRESSUER DALAM MEMPERCEPAT PERSALINAN KALA II
}

\author{
Durrotun Munafiah ${ }^{1}$, Sari Utami Hi. Wahab ${ }^{2}$ \\ ${ }^{1,2}$. STIKes Karya Husada Semarang \\ E-mail: durrotunmunafiah313@gmail.com
}

\begin{abstract}
ABSTRAK
Persalinan merupakan proses membuka dan menipisnya serviks sehingga janin turun kedalam jalan lahir. Nyeri selama proses persalinan merupakan kondisi yang fisiologis. Namun, jika dibiarkan nyeri dapat mempengaruhi kondisi ibu berupa kelelahan, kecemasan dan menimbulkan stress yang mengakibatkan penyempitan pembuluh darah dan mengurangi aliran darah yang membawa oksigen ke rahim sehingga terjadi penurunan kontraksi rahim yang akan menyebabkan memanjangnya waktu persalinan. Salah satu cara untuk mengurangi rasa nyeri dengan cara non-farmakologi yaitu counter-pressure. Mengetahui pengaruh asuhan counter-pressure pada persalinan multipara terhadap lama kala II di RSUD KRMT Wongsonegoro. Jenis penelitian ini adalah kuantitatif dengan metode true eksperimen menggunakan rancangan post test control group design. Sampel penelitian sebanyak 36 ibu bersalin multipara. Teknik pengambilan sampel dilakukan dengan menggunakan accidental sampling. Analisis menggunakan uji Independent sample t-test. Rata-rata lama kala II pada kelompok kontrol adalah 34.56, rata-rata lama kala II pada kelompok eksperimen adalah 21.00. Uji Independen sample t-test menunjukkan bahwa ada perbedaan lama kala II pada kelompok kontrol dan kelompok eksperimen dengan nilai $p$-value $0.000(p<0,05)$. Ada pengaruh asuhan counter-pressure pada ibu bersalin multipara terhadap lama kala II.
\end{abstract}

Kata kunci : Counter-pressure; lama kala II

\section{THE EFFECT OF COUNTER-PRESSURE CARE ON MULTIPARA MATERNAL TOWARDS THE SECOND-STAGE DURATION}

\begin{abstract}
Labor is the process of opening and thinning the cervix so that the fetus descends into the birth canal. Labor pain is a physiological condition, however, untreated labor pain can affect the mother condition in the form of fatigue, anxiety and stress-induced constricted blood vessels. The effect of blood vessel constriction is the reduction in blood flow tha carries oxygen to the uterus then reducing the uterine contractions that lead to prolonged labor time. One way to reduce pain in non-pharmacological is by using counter-pressure. This study was to know the influence of counter-cpressure care on multiparamaternal women towards the second-stage duration at KRMT Wongsonegoro Regional General Hospital. This research was quantitative with true experimental method by using post test control group design. The sample of this research were 36 multipara maternal women. The sampling technique used accidental sampling. The analysis was conducted independent by sample $t$-test. The mean of second stage in control group is 34.56 , the mean of the second stage in the experimental group is 21.00 . The Independent sample t-test shows that there is a difference in the second stage of in the control group and the experimental group with $p$-value $=0.000(\mathrm{p}=<0.05)$. There is influence of counter-pressure care in multipara maternal women in the second-stage duration.For mothers, the families, the health workers, hospitals, and the researchers should be give the caring especially the counter-pressure in order to help reduce pain, anxiety and stress of maternity mothers to make deliveries run smoothly and quickly.
\end{abstract}

Keywords : Counter-pressure; second-stage duration 


\section{Pendahuluan}

Kematian ibu pada tahun 2015, sekitar 99\% (302.000) kematian maternal global terjadi di daerah berkembang, dengan sub-Sahara Afrika mencapai 66\% (201.000). Untuk setiap 100.000 kelahiran hidup, 450 wanita meninggal selama tiga periode (kehamilan, persalinan, atau pascapersalinan) di negara-negara berkembang (Bililign N, 2017).

Menurut Survei Demografi dan Kesehatan Indonesia (SDKI) di Indonesia tahun 2012, angka kematian ibu di Indonesia masih tinggi sebesar 369 per 100.000 kelahiran hidup (Sutarjo S, 2014). Untuk Provinsi Jawa Tengah jumlah Angka Kematian Ibu (AKI) tahun 2013 berdasarkan laporan dari kabupaten/kota sebesar 118,62/100.000 kelahiran hidup (Samhasto P, 2013). Berdasarkan data di Kota Semarang laporan Puskesmas jumlah kematian ibu maternal pada tahun 2015 sebanyak 35 kasus dari 27.334 jumlah kelahiran hidup atau sekitar 128,05 per 100.000 kelahiran hidup (Widoyono, 2015).

Penyebab langsung kematian ibu di Indonesia terkait kehamilan dan persalinan adalah perdarahan sebesar 28\%, eklamsi sebesar 24\%, infeksi sebesar 11\%, partus lama sebesar 5\%, dan abortus sebesar 5\% (Prawitasari E, 2015). Persalinan merupakan proses membuka dan menipisnya serviks sehingga janin turun kedalam jalan lahir (Rahmawati R, 2013). Nyeri persalinan dapat mempengaruhi kontraksi uterus melalui sekresi kadar katekolamin dan kortisol yang menaikkan aktivitas uterus yang tidak terkoordinasi yang akan mengakibatkan persalinan lama. Rasa cemas akibat nyeri tersebut dapat menyebabkan terjadinya persalinan yang lama sehingga kekuatan (tenaga untuk mengejan) ibu akan habis saat persalinan tersebut (Rahmawati $\mathrm{R}, 2013)$.

Berdasarkan studi pendahuluan yang dilakukan di RSUD KRMT Wongsonegoro pada bulan Januari sampai Mei 2017 terdapat jumlah persalinan spontan sebanyak 645 dengan kejadian lama kala II sebesar 2,25\%. Survey yang dilakukan peneliti terhadap bidan tentang tindakan yang dilakukan pada saat menjelang persalinan (kala I) untuk membuat pasien merasa nyaman dan rileks serta mengurangi nyeri yaitu dengan menyarankan pasien melakukan relaksasi pernapasan hal ini diajarkan kepada keluarga pasien. Berdasarkan data dan survey diatas peneliti tertarik untuk melakukan penelitian terhadap pengaruh asuhan counter-pressure yang diberikan pada pasien selama kala I terhadap kejadian lama kala II.

\section{Tinjauan Teoritis}

Persalinan normal menurut WHO (World Organization Healt) adalah persalinan yang dimulai secara spontan, berisiko rendah pada awal persalinan dan tetapi demikian selama proses 
persalinan, bayi lahir secara spontan dalam presentasi belakang kepala dan usia kehamilan 37-42 minggu lengkap dan setelah persalinan ibu maupun bayi berada dalam kondisi sehat. Persalinan adalah akhir dari kehamilan normal pada manusia; Kisaran untuk ini adalah 37-42 minggu. Meski perkiraan tanggal persalinan adalah 280 hari sejak hari pertama menstruasi terakhir, hanya 3-5\% wanita yang melahirkan sesuai taksiran mereka (Oktarina M, 2016).

Setiap fase persalinan terjadi peningkatan kecemasan. Dengan makin majunya proses persalinan, menyebabkan perasaan ibu hamil semakin cemas, maka akan semakin meningkatkan intensitas nyeri. Sensasi nyeri yang diderita ibu bersalin berasal dari sinyal nyeri yang timbul saat otot rahim berkontraksi dengan tujuan untuk mendorong bayi yang ada didalam rahim keluar. Rasa cemas akibat nyeri tersebut dapat menyebabkan terjadinya persalinan yang lama sehingga kekuatan (tenaga untuk mengejan) ibu akan habis saat persalinan tersebut (Dewi R, 2013).

Ada banyak metode untuk menghilangkan nyeri persalinan, baik non-farmakologis maupun farmakologis. Metode penghilang rasa nyeri yang ideal harus aman, efektif, tepat waktu, efisien, adil, berpusat pada perempuan dan idealnya tidak boleh mengganggu persalinan atau mobilitas wanita (Maguire S, 2008). Pada penelitian sebelumnya peneliti menggunakan metode non-farmakologi yaitu counter-pressure yang merupakan pijatan tekanan kuat di daerah panggul untuk melihat dampaknya pada nyeri persalinan (Dewi R, 2013).

Dalam penelitian ini peniliti menggunakan metode yang sama yaitu counter-pressure dengan melihat dampaknya pada proses persalinan kala II, sehingga dalam penelitian ini dapat membantu mengurangi rasa nyeri serta proses persalinan yang lebih pendek terutama pada kala II pada ibu bersalin primipara maupun multipara.

\section{Metode Penelitian}

Jenis penelitian ini merupakan penelitian kuantitatif dengan metode true eksperimental dengan mengungkapkan hubungan sebab akibat dengan cara melibatkan kelompok kontrol disamping kelompok eksperimental. Penelitian dilaksanakan di RSUD KRMT Wonsonegoro pada bulan Desember 2017 dengan jumlah populasi yaitu seluruh ibu bersalin normal pada bulan Desember 2017. Teknik pengambilan sampel yang digunakan adalah accidental sampling. Variabel yang diukur adalah lama kala II dalam proses persalinan pada kelompok kontrol dan eksperimen. Instrumen penelitian menggunakan SOP asuhan counter-pressure, lembar observasi lama kala II dan jam/stopwatch. Uji normalitas data menggunakan Shapiro wilk dengan hasil data berdistribusi normal maka analisis data menggunakan uji Independent sample t-test ( 


\section{Hasil Penelitian}

Tabel 1. Distribusi frekuensi lama kala II ibu bersalin multipara pada kelompok kontrol yang tidak diberi asuhan counter-pressure

\begin{tabular}{cccccccc}
\hline Lama Kala II & Mean & Median & Modus & Min & Max & SD & N \\
\hline Kontrol & 34.56 & 35.00 & 35 & 15 & 50 & 10.060 & 18 \\
\hline Eksperimen & 21.00 & 17.50 & 10 & 8 & 40 & 10.267 & 18 \\
\hline
\end{tabular}

Berdasarkan tabel 1 menunjukkan bahwa rata-rata lama kala II persalinan pada kelompok kontrol yang tidak diberikan asuhan counter-pressure adalah 34.56 menit (SD = 10.060), dengan median 35.00 menit dan lama kala II yang paling banyak dialami responden adalah 35 menit, sedangkan durasi terpendek pada kala II adalah 15 menit dan durasi terlama adalah 50 menit. Rata-rata lama kala II persalinan pada kelompok eksperimen yang diberikan asuhan counterpressure adalah 21.00 menit $(\mathrm{SD}=10.267)$, dengan median 17.50 menit dan lama kala II yang paling banyak dialami responden adalah 10 menit, sedangkan durasi terpendek pada kala II adalah 8 menit dan durasi terlama adalah 40 menit.

Tabel 2. Distribusi perbedaan rata-rata lama kala II pada kelompok kontrol yang tidak diberi asuhan counter-pressure dan pada kelompok eksperimen yang diberikan asuhan counter-pressure.

\begin{tabular}{cccccc}
\hline Kelompok & N & Mean & Median & SD & $P$-Value \\
\hline Kontrol & 18 & 34.56 & 35.00 & 10.060 & 0.000 \\
Eksperimen & 18 & 21.00 & 17.50 & 10.267 & 0.000 \\
\hline
\end{tabular}

Berdasarkan data pada tabel 2 didapatkan hasil bahwa mean rank lama kala II pada kelompok kontrol yang tidak diberi asuhan counter-pressure adalah 34.56 sedangkan pada kelompok eksperimen yang di beri asuhan counter-pressure adalah 21.00. Hasil uji statistik didaptkan nilai $p$-value $=0.000(p<0,05)$, maka dapat disimpulkan bahwa ada perbedaan yang signifikan lama kala II pada kelompok kontrol dan kelompok eksperimen.

\section{Pembahasan}

Berdasarkan hasil penelitian dapat diketahui bahwa rata-rata lama kala II ibu bersalin multipara pada kelompok kontrol yang tidak diberi asuhan counter-pressure adalah 34.56 menit. Jumlah presentasi ibu yang mengalami kala II < 30 menit adalah 27,8\% sedangkan yang mengalami kala II > 30 menit adalah 72,22\%. 
Hasil penelitian ini di dukung oleh penelitian yang dilakukan oleh Rahmawati, lama kala II dapat diketahui 90 Persen responden yang mendapat perlakuan massase punggung bisa melahirkan bayi pada 30 menit pertama setelah dinyatakan pembukaan lengkap. Pada kelompok kontrol hanya 40 Persen yang melahirkan pada kala II 30 Menit pertama Rahmawati dkk (2013).

Berdasarkan hasil penelitian dapat diketahui bahwa rata-rata lama kala II ibu bersalin multipara pada kelompok eksperimen yang diberi asuhan counter-pressure adalah 21.00 menit. Jumlah presentasi ibu yang mengalami kala II < 30 menit adalah 77,8\% sedangkan yang mengalami kala II > 30 menit adalah 22,22\%.

Hal ini di dukung oleh penelitian yang dilakukan oleh Abdolahian, Ghavi, Abdollahifard dan Sheikhan yang mengatakan bahwa ibu yang di pijat baik di punggung atau sakrum pada tahap pertama persalinan atau pada perineum di tahap kedua, melaporkan penurunan rasa sakit dan juga memiliki persalinan yang jauh lebih pendek, tinggal di rumah sakit yang lebih pendek dan lebih sedikit mengalami depresi pasca melahirkan Abdolahian dkk (2014).

Counter-pressure pada penelitian ini secara statistik bisa membantu ibu beradaptasi dengan nyeri. Ketika Ibu sudah merasa tenang dan rileks maka rasa takut yang muncul dapat teratasi sehingga pengeluaran adrenalin yang berlebih dapat diantisipasi, zat-zat penghambat rangsang nyeri pun dapat disekresikan dengan baik. Dengan berkurangnya adrenalin maka pembuluh darah dapat bervasodilatasi dengan baik, sehingga dapat memperlancar aliran darah yang membawa oksigen ke rahim. Ketika oksigen dalam rahim tercukupi maka kontraksi dapat berjalan dengan baik, sehingga ibu mampu meneran dengan maksimal yang akan mengakibatkan kelancaran pada persalinan khususnya kala II Rahmawati dkk (2013).

Berdasarkan hasil penelitian yang dilakukan dapat diketahui bahwa rata-rata lama kala II pada kelompok kontrol yang tidak diberikan asuhan counter-pressure adalah 34.56 sedangkan rata-rata lama kala II pada kelompok eksperimen yang diberikan asuhan counter-pressure adalah 21.00. Hasil uji statistik menggunakan Independent sample T-tes pada kelompok kontrol dan eksperimen di dapatkan hasil $p$-value $=0,000(p=<0,05)$ yang artinya Ho ditolak Ha diterima, maka terdapat perbedaan yang signifikan lama kala II pada kelompok kontrol dan kelompok eksperimen. Oleh karena itu, dapat di simpulkan ada pengaruh pemberian asuhan counterpressure terhadap lama kala II pada ibu bersalin multipara.

Hal ini menunjukkan bahwa kelompok yang tidak diberi asuhan counter-pressure memiliki rata-rata lama kala II yang lebih lama yaitu 34.56 menit, namun pada kelompok yang diberi asuhan counter-pressure memiliki rata-rata lama kala II lebih cepat yaitu 21.00 menit, sehingga 
membuktikkan bahwa asuhan counter-pressure dapat mempercepat proses persalinan khususnya kala II.

Hasil penelitian ini di dukung oleh penelitian Sari dan Pantiawati, bahwa teknik massase membantu ibu merasa lebih segar, rileks dan nyaman selama persalinan. Sebuah penelitian menyebutkan, ibu yang di massase 20 menit setiap jam selama tahapan persalinan akan lebih bebas dari rasa sakit. Hal itu terjadi karena massase merangsang tubuh melepaskan senyawa endorphine yang merupakan pereda sakit alami. Endorphine juga dapat menciptakan perasaan nyaman dan enak sehingga mengurangi kecemasan yang ibu rasakan. Teknik massase yang digunakan yaitu counter-pressure yang merupakan pijatan tekanan kuat dengan cara meletakkan tumit tangan atau bagian datar dari tangan, atau juga menggunakan bola tenis pada daerah lumbal dimana ia sedang mengalami sakit punggung Sari dkk (2013).

Dalam persalinan, pijat juga membuat ibu merasa lebih dekat dan merasa diperhatikan oleh orang yang merawatnya. Sentuhan seseorang yang peduli dan ingin menolong merupakan sumber kekuatan saat ibu sakit, lelah dan cemas. Saat memijat harus memperhatikan respon ibu, apakah tekanan yang diberikan sudah atau belum. Hal ini sesuai dengan studi yang dilakukan di Iran oleh Najafi dan Roudsari menunjukkan bahwa dukungan yang diberikan secara terus menerus oleh bidan selama persalinan menurunkan intensitas rasa sakit, lama persalinan dan kejadian depresi pasca persalinan Najafih dkk (2017).

\section{Kesimpulan}

Ada pengaruh signifikan asuhan counter-pressure terhadap lama persalinan kala II.

\section{Saran}

Bagi pasien diharapkan Ibu bersalin lebih kooperatif dalam menghadapi persalinan. Bagi keluarga diharapkan bisa turut berpartisipasi dalam memberikan kenyamanan pada ibu bersalin sehingga dapat membantu ibu melalui proses persalinan. Bagi Tenaga Kesehatan/Profesi diharapkan dapat mempelajari asuhan counter-pressure sehingga bisa diterapkan pada pasien dan juga dapat meningkatkan keterampilan dan pengetahuan. Bagi Instansi/RSUD diharapkan dapat menerapkan kebijakan terkait pemberian asuhan dengan teknik counter-pressure pada setiap ibu bersalin normal sehingga dapat mengurangi nyeri dan meminimalisrikan kejadian lama kala II dan juga dapat membuat ibu bersalin merasa nyaman serta rileks dalam menghadapi persalinannya. Bagi Peneliti Selanjutnya diharapkan bagi peneliti selanjutnya untuk dapat mengembangkan variabel penelitian dan sampel penelitian yang lebih banyak. 


\section{Daftar Pustaka}

Abdolahian, S.; Ghavi, F.; Abdollahifard, S.; Sheikhan F. (2014). "Effect of Dance Labor on the Management of Active Phase Labor Pain \& Clients' Satisfaction: A Randomized Controlled Trial Study." Global Journal Of Health Science,

Bililign, N.; Mulatu, T. (2017). “Knowledege of Obstetric Danger Sign and Associated Factors Among Reproductive Age Women in Raya Kobo District of Ethiopia: A Community Based Cross-sectional Study.” BMC Pregnancy Childbirth.

Dewi, R.. 2013. Pengaruh Teknik Counter-Pressure Terhadap Tingkat Nyeri pada Pasien Inpartu Kala I Fase Laten.

Maguire, S. 2008. The Pain Of Labor. Reviews In Pain. Vol. 2, No. 2.

Najafi, F.; Roudsari, L.; Ebrahimipour, H. (2017). "The Best Encouraging Persons in Labor: A Content Analisys of Iranian Mothers Experiences of Labor Support.” Plos One.

Nursalam. (2013). Metodologi Penelitian Ilmu Keperawatan. Jakarta: Salemba Medika

Prawitasari, E.; Yugistyowati, A.; Kartika, D. (2015). "Penyebab Terjadinya Rupture Perineum pada Persalinan Normal.” Jurnal Ners dan Kebidanan, vol.3, no.2.

Rahmawati, R.; Arifa, S.; Widiastuti, A. (2013). "Pengaruh Pijat Punggung Terhadap Adaptasi Nyeri Persalinan Fase Aktif Lama Kala II dan Perdarahan Persalinan pada Primigravida.” Jurnal Kesehatan Masyarakat Nasional, vol.8, no.5.

Sari, K; Pantiawati, I. (2013). "Perbandingan Teknik Massase dan Terapi Musik Terhadap Penurunan Kecemasan pada Ibu Bersalin Primipara.” Jurnal Ilmiah Kebidanan.

Santjaka. (2011). “Statistik untuk Penelitian Kesehatan.” Yogyakarta: Nuha Medika.

Samhasto. (2013). Profil Kesehatan Jawa Tengah.

Sutarjo., Primadi., Yudianto., Budijanto., Hardhana., \& Soenardi. (2014). Profil Kesehatan Indonesia.

Widoyono, Pramudiyanto., Endang., Prayitno., Pandu., Nugraheni., dkk. (2015). Profil Kesehatan Kota Semarang. 